\title{
Introduction to the Third Edition
}

It is twenty years since the first publication of our book about the British army and the Passchendaele campaign, formally called the Third Battle of Ypres, and it is fifteen years since the second edition appeared. Despite the flood of books on the First World War published during the interim, none that we have seen deals with the entire campaign in both its military and political dimensions, although some studies have focused on aspects of the battle.

It might be useful, therefore, to restate the book's main arguments before turning to the other literature that has appeared in order to see how or if it might modify some of those arguments.

The first of our contentions is that the British army was, in the second half of 1917, better placed to conduct offensive operations on the Western Front than on any previous occasion. Partly, this situation had come about because of the enormous productive capacity of the British Ministry of Munitions. Whereas during the Somme campaign in 1916 only a handful of the array of guns had been heavy enough to ensure comprehensive trench destruction, at Passchendaele no fewer than 750 heavy guns were available. Moreover, these guns had a plentiful supply of shells to fire at the German defences.

There were other factors that should have worked to the advantage of the British. During the Somme campaign it had been discovered that a curtain of artillery shells fired immediately in front of the advancing infantry was useful in neutralising the German machine gunners who had taken such a fearful toll on the infantry on the first day. By the end of July 1916, the 'creeping barrage', as it was called, was in general use in all infantry attacks. Further refinements had taken place during the campaigns at Arras and the Vimy Ridge, where it had been realised that if the barrage was slowed and made thicker by 
firing more shells, it wrought more havoc on the enemy and gave British soldiers a better chance of keeping up with its rate of advance, thereby offering more protection.

Since the Somme there had also been some advances in artillery accuracy. A method of detecting the location of distant German guns, called sound ranging, was starting to be used and the various meteorological factors that affected the flight of a shell, such as air temperature and wind speed, were noted with greater regularity. Matters such as the wear on the rifling of a gun and an accurate measure of the weight of each shell being fired also aided accuracy. By mid-1917 there was certainly a greater chance that a shell would hit the target at which it had been aimed.

The Somme saw another innovation in the form of the tank. This weapon was first used on 15 September, and although it did not lead to spectacular successes, at least, when the going was good, it did allow the infantry to make gains at modest cost. The tanks certainly startled the German defenders whom they bore down upon and at times caused to panic. Although the mechanical unreliability of the vehicles and their inability to manoeuvre over rough ground limited their effectiveness, in 1917 a new model tank, the Mark IV, offering greater reliability, became available.

There was another lesson to be learned from the Somme and the early battles of 1917: the efficacy of the limited advance. On each occasion it had been used, when the objective of Haig's armies had been modest, it had succeeded. In 1916, the capture of Pozières and Thiepval and the operations of 25 September, and the seizure of the Vimy Ridge the following year, all pointed the way forward. The lesson of 14 July was more ambiguous, however. Then, the objective of capturing the German second position had been achieved with relative ease because of the weight of artillery fire directed against it. But all attempts to exploit that initial success had failed dismally. The cavalry could not get through and neither could the foot soldiers. The German defences and their defenders behind the front remained intact and resisted all attempts to dislodge them.

The lessons from other episodes on the British front were not ambiguous at all. The breakthroughs planned for 1 July, 15 September and 9 October 1916, like the attempt to break through at Arras, had all failed disastrously. The reason was not obscure. By trying to destroy all the enemy defences, Haig had spread the artillery too thinly to destroy any of them - at least to the extent he needed for a breakthrough. And so here was the lesson: while the unlimited objective was beyond the 
means of the British, a limited 'bite and hold' operation could achieve success and in most cases kill more enemy soldiers than were lost by the attacking force.

The Somme offered another great lesson: artillery superiority, a well-fired creeping barrage and trained infantry were all futile in poor weather. When rain reduced the battlefield's ravaged terrain to a quagmire, the aircraft that were vital to the gunners in spotting the fall of shot were grounded. Low cloud also hampered direct observation for the guns. In addition, the creeping barrage was useless if the mud made it difficult for the soldiers to even get out of their own trenches. In any case, under such conditions they would be unable to follow the protective curtain of shells because even walking at a slow pace was impossible. Rain and mud were immediate indicators that extensive military operations should be shut down.

Haig was no technophobe. He would use any and all of the resources and technological breakthroughs - guns, shells and tanks - that the Ministry of Munitions could make available to him. And he would give experts in artillery accuracy free rein to apply their new techniques. Haig's grasp of other developments, however, was not so positive. The new offensive, he had decided, would be to attack out of the Ypres salient and sweep all the way to the Belgian coast, thereby outflanking the entire German line in Flanders and northern France. Haig's audacious plan reveals a number of things. Firstly, it indicates that he had by no means given up the unlimited offensive, despite the fact that it had failed on every occasion he had attempted it. Once more the cavalry would be readied and the artillery spread too thinly across a number of objectives.

Perhaps even more important was the geographical location of the offensive. The Ypres salient was in northern Belgium, a region notorious for short, wet summers and long, foggy, even wetter winters. We noted earlier than many of the improvements made at the Somme and later (the creeping barrage, the tank, aerial spotting, rapid movement of infantry) would cease to count in such conditions. So Haig was relying on fine weather in a region where as a matter of course it was in short supply.

There were other disadvantages in the selection of Ypres. The entire salient was overlooked at moderate range by the Messines Ridge and at closer range by the Gheluvelt Plateau, both to the south of the main battlefield. Both ridges would need to be secured before operations began at Passchendaele to deny the enemy observation over the salient. As it happened, just such an operation for Messines had long been planned. Since 1915, tunnellers had been laying a series of enormous 
mines (in fact, large concentrations of TNT) under the ridge, with the intention that, at zero hour, the mines would blow the top off the ridge and British troops would rush forward and occupy it. This work was now nearing completion. No such careful plans had been or were made regarding the Gheluvelt Plateau although it too allowed the Germans observation of any British preparations for the main offensive.

Then there was the matter of who might command the new venture. General Plumer, whose Second Army was at Messines, seemed a logical choice, and General Rawlinson of the Somme was sent north to develop some plans; but in the end neither was given the job. Instead it went to an army commander with a consistent record - but only in the sense that it had been consistently bad. General Gough, who had presided over such disasters as the Somme's Pozières-Mouquet Farm campaign (which hardly seemed to have any point at all, and which got nowhere at great cost), and the poorly thought-out Battles of Bullecourt in early 1917, was deemed by Haig to be just the man to command the new campaign. Gough, in Haig's eyes, had one great advantage: he was a thruster, who would brook none of the cautious step-by-step plans brought forward by Plumer or Rawlinson, and who offered to dash through to the Belgian coast in the manner that Haig expected. His previous record was disregarded as merely a sign of heretofore limited opportunity. And in one sense, Haig was correct: Mouquet Farm and Bullecourt had been subsidiary operations. Now Gough was being given a chance to bring his unmatched incompetence to something altogether more substantial.

And bringing in a new man, whoever he was, had another major disadvantage. The Messines operation, which would be commanded by Plumer, would have to precede the attack from the salient. The advantage of leaving Plumer in place for that major attack was that he was familiar with the entire area and could be expected to follow up Messines speedily with a new plan. A new commander would need time to familiarize himself with the ground, draw up a plan and allow for troops and guns to be transferred from the Second Army to his own. By insisting on Gough, Haig thereby introduced a seven-week gap between Messines and the main operation. As it happened, this was ample time for the Germans to reorient their entire defensive system opposite the salient.

The Messines operation began on 7 June and was an initial success. The mines destroyed the German front positions on the ridge which were rapidly occupied by the British infantry. But Haig had insisted that the troops continue down the ridge to occupy a further section of 
German positions. This did not go well. Those German guns beyond the range of the British preliminary bombardment opened fire on the now unprotected troops. Little ground was gained at high loss. The lesson of the efficacy of 'bite and hold' operations should have been reinforced by this failure to apply it, but there was no indication that anyone from GHQ drew this conclusion.

Certainly, when the main operation opened seven weeks later on 31 July, the unlimited objective - the Passchendaele Ridge and then the Belgian coast - was still in place. As an operation in its own right the first day was a modified success. The immense weight of shells thrown at the defenders inflicted as many casualties upon them as were suffered by the attackers $(27,000)$. The Pilckem Ridge, on the left of the front, was captured and in all eighteen square miles of ground was gained. In this sense the opening day cannot be compared to the disastrous first day of the Somme campaign. In another sense, however, it can. The gains had been modest; the Passchendaele Ridge was still distant, let alone the Belgian coast; and it would take a long succession of similar operations before either of those objectives hove into view. This entailed the guns having to be dragged forward for each new attack, a process that would take an immense amount of time. Moreover, the depth of the German defensive system, much improved in that sevenweek hiatus, had hardly been touched. No fewer than three defensive positions (Flandern I, II and III) now stood between the British and Passchendaele, and many more concrete pillboxes between those lines meant that the artillery would be required to subdue whole areas instead of mere lines of trenches. In addition, the first day had not seen any ground gained against the Gheluvelt Plateau on the right. Defences there had required a heavier bombardment than had been allocated by Gough and were still intact. As a result, the Germans could still observe every detail of British activity in the salient. Surprise was still at a discount.

The operations for the month following the first day demonstrated that Gough and GHQ had failed to take on board one of the main lessons of the Somme - that is, that in the war they were fighting, military operations would invariably fail in poor weather. That was certainly demonstrated at Passchendaele in August. On the 1st, rain began to fall and it hardly let up for the entire month. The ground around Ypres, already low-lying and swampy, became a quagmire, worsened by the constant shelling's pummelling of the high water table. The movement of even the light guns of the field artillery was well-nigh impossible. Air support, in the form of aerial photography 
or spotting for the artillery, was also out of the question. Tanks could not operate. The soldiers could barely get out of their trenches to attack, let alone follow a creeping barrage.

Yet Gough and GHQ persisted in ordering attack after attack. The ground gained in any one of these futile endeavours was derisory. Indeed, the ground gained in the entire month could only be seen on a large-scale map. And no ground at all had been gained across the vital Gheluvelt Plateau. Gough resorted to the last refuge of the incompetent: he blamed the troops for his own myopia. This was too much even for Haig. Towards the end of August Gough was sidelined and Plumer given the task of taking the plateau. Yet, inexplicably, Gough was not told to desist in his endeavours. Attacks on his reduced front continued well into September, and accomplished nothing except to increase the casualty list. Haig looked on, a spectator in his own headquarters.

Plumer insisted on what Gough should have demanded: the time to prepare a concerted attack, and dry weather in which to conduct it. Haig acquiesced and the weather obliged - there was hardly any rain at all in September - and by the 20th, Plumer was ready. This phase of the Battle of Passchendaele has tended to fade in popular memory, while the mud is only too well remembered. Yet for Plumer's battles, perversely, it was the mud's residue that posed the problem: the dust kicked up by the falling shells obscured aerial observation much as August's rain and cloud had done, albeit not to the same extent; on most occasions the fall of shot could be observed.

In any case, Plumer was using a new method - or rather, a refinement of previous successful 'bite and hold' operations. He fought three battles to capture the Gheluvelt Plateau. Each had a strictly limited objective - sometimes just 1,000 yards from the start line. Each was accompanied by the heaviest artillery barrage seen thus far on the Western Front. And when the final objective had been reached, the artillery continued to protect the infantry by firing a barrage in front of them to a depth of 1,000 yards; if the Germans wanted to retake the ground lost they would have to counter-attack through this deluge of shells. That the Germans did attempt this suggests that the British were not the only army to dismiss the lessons of the Somme. Needless to say their every effort failed, with heavy casualties.

All three of Plumer's battles on the Gheluvelt Plateau - Menin Road on 20 September, Polygon Wood on 26 September and Broodseinde on 4 October - were successful. Nevertheless, even with the unprecedented heavy artillery barrages, the German pillbox defence system was so strong that British casualties were far from negligible. Moreover, the 
ground gained was not extensive (some 3,500 yards). However, the lesson was again driven home that such attacks could inflict heavy losses on the defence and gain some ground. The Germans might hold their men back out of range of the British guns or pack them forward in order to attempt to hold their line. In the former instance they fell victim to the British standing barrages when they did attempt to counter-attack; in the latter they lost heavily during the bombardments that preceded the attack. Above all this course of events proved that the Germans had no answer whatsoever to the new tactics. The only proviso was that they required good weather.

So when the rains again started to fall after Broodseinde in early October, all logic pointed to the British closing down the offensive until the new year. But Haig and, more remarkably, Plumer had become obsessed with obtaining the Passchendaele Ridge. As all thought of reaching the Belgian coast had long receded, this was an objective of no strategic importance. It was also a dubious tactical objective, as to reach it required the armies to attack into a valley before they reached the ridge's slope. Nevertheless, attempt after attempt was made. This is the period that fixed 'Passchendaele' as the overall name for the campaign and bestowed its evil reputation upon it.

The line did slowly move towards the ridge but the mud was so bad that soldiers often had to crawl forward because they could not stand. To stray from the duckboard paths was to risk drowning in the mire. Aerial and artillery support were negligible in this period. The Australians, the New Zealanders, the British and the Canadians all struggled forward. Finally the Canadians did secure a small section of the ridge and Haig declared a success. But only in his eyes would it be thus remembered. The British suffered 275,000 casualties; the Germans something under 200,000. Not even the most blatant casuistry from the British Official Historian could alter this equation. The territory gained was so insignificant that when the Germans attacked in March 1918 it was evacuated in four days without weakening the British position.

There is an interesting political aspect to this miserable affair. The prime minister who came to office in December 1916 took the dimmest view of the activities of the British high command on the Western Front. Lloyd George had such a low opinion of Haig that he placed him under the operational control of Nivelle, the untested French general, for the 1917 spring offensive. The resulting fiasco demonstrated that the British had no monopoly on second-rate commanders. So when it came to planning the summer offensive, all Lloyd George's reservations about the command resurfaced. He declared that Haig's plan had 
little chance of success and in the end agreed to sanction only the first phase of the operation, after which, and in light of the results achieved, he would revisit his decision. This was rather lame but constitutionally appropriate; in Britain, civilian authorities, not soldiers, sanctioned military campaigns.

Yet by the time September arrived, and with the Flanders campaign operational for two months, neither Lloyd George nor the War Cabinet had sent word. They spent much time trying to coax Italy into futile campaigns, or inducing Russia, then in a pre-revolutionary phase, to prosecute the war more vigorously. But when it came to the only campaign that mattered, and the only army that might force a victory in the West, they were silent. Although the British army was getting nowhere and was being worn down in the process, the civilian leadership would not pay attention. When they did finally get around to discussing the Western Front there was much hand-wringing but no decisions. Lloyd George himself predicted that Haig's offensive would get nowhere and assured the War Cabinet that he would draw this lamentable fact to their attention at the appropriate time.

This dereliction on the part of the civilian authorities in Britain is often put in terms that defy common sense - that Lloyd George did not dare move against Haig because of the King's support for the commander-in-chief. But there is no substance to this. Lloyd George was not required to remove Haig (there was indeed no obvious successor) only to tell him that the year was so advanced that he should close down the offensive. Whatever else he was, Haig was a good constitutionalist, and there is no doubt that he would have agreed. Why then was this course not taken? The answer must be that in some sense Lloyd George and Haig were as one. Lloyd George had come to power offering to deliver a 'knock-out blow' to Germany. In late 1917 only Haig was offering such a punch, and, against his better judgement, Lloyd George hoped the commander-in-chief might land it. When Haig fell short the recriminations were bitter not because the two men were so opposed in their desired outcomes but because they were so close. Whatever the prime minister's motivation, however, the fact is that he presided over - and bore ultimate responsibility for - one of the most dismal and futile campaigns ever fought by the British army.

In the two decades since we first published this book, has there emerged new scholarship on the Passchendaele campaign that might lead us to substantially alter any of the conclusions given in outline above? The short answer is no. It is remarkable that since 1996 there has not been 
a single overall assessment of the campaign. As we will detail, there have been some studies on aspects of the battle, but nothing with which to compare this book.

Two works do deal with the battle as a whole but from the perspective of the individual soldier. The first, by Peter Barton (with research by Jeremy Banning), is Passchendaele, a lavishly illustrated volume with many extracts of soldiers' diaries and letters housed in the Imperial War Museum and many other archives. ${ }^{1}$ While it provides some narrative, its main purpose is to tell the story of the campaign as the individual soldier experienced it. The illustrations are particularly well chosen and the incorporated maps (some being military maps from the period) are a useful accompaniment. The second book, which shares largely the same purpose and is also replete with extracts of diaries and letters from the Imperial War Museum, is Passchendaele: the Sacrificial Ground by Nigel Steel and Peter Hart. ${ }^{2}$ The authors explain that their account of the battle consists of 'the personal experiences of the men who had to endure the consequences of command decisions that they could not possibly influence'. Such a work is useful for telling us what conditions were like for those who had to participate in the battle. But it requires a different kind of source material to explain what they were being called upon to attempt in the larger context of the war. That was our concern.

A work of a somewhat different kind is Passchendaele in Perspective, edited by Peter H. Liddle, consisting of a variety of essays dealing with different aspects of the campaign. ${ }^{3}$ Many of these have real merit - in particular, Andrew Wiest is worth reading on the planned, but never carried out, assault from the sea behind the German front line; and Ashley Ekins is also concise and authoritative on the Australian contribution to the battle. What the book lacks is a controlling mind to provide an overall narrative.

A good example of the contribution of a single nation to the campaign is provided by Glyn Harper in his Dark Journey, an account of three major New Zealand battles. ${ }^{4}$ Anyone requiring detail of the dreadful conditions during the late period of the offensive can do no better than to read his description of the New Zealand Division on 12 October.

${ }^{1}$ Peter Barton (with research by Jeremy Banning), Passchendaele (London: Constable, 2007).

${ }^{2}$ Nigel Steel and Peter Hart, Passchendaele: the Sacrificial Ground (London: Cassell, 2000).

3 Peter H. Liddle (ed.), Passchendaele in Perspective (London: Leo Cooper, 1997).

${ }^{4}$ Glyn Harper, Dark Journey: Three Key New Zealand Battles of the Western Front (Auckland: HarperCollins New Zealand, 2007). 
A general book that makes a useful addition to the literature is Jack Sheldon's The German Army at Passchendaele. ${ }^{5}$ This is a collection of translated extracts from the diaries, letters and memoirs of German soldiers who fought in the battle. In the main it eschews analysis, while at the same time indicating that the campaign was a terrible ordeal for the defenders as well as the attackers. When Sheldon does engage in analysis his findings tend to back up our own. He goes into some detail on casualty statistics and arrives at the conclusion that the allies suffered to a greater extent than the Germans, though the margin was much narrower than at the Somme.

One book adds to the lamentable story of the last days at Passchendaele. ${ }^{6}$ Michael LoCicero has discovered an abortive and futile action after the battle had been formally closed down. The action was cancelled by GHQ but somehow went ahead anyway with the usual lack of results.

There is a useful book by Jim Beach, Haig's Intelligence, which has a chapter on Passchendaele. ${ }^{7}$ It rather reinforces our point that Haig was fed material of the type he wished to hear by his chief of intelligence, Charteris. Any variant on this method would no doubt have been overlooked. Such was the sorry state of command in 1917.

The reliable Sanders Marble could, in our view, have given more space to the Plumer phase of the campaign in his British Artillery on the Western Front. ${ }^{8}$

In sum, the new literature has enriched our understanding of some aspects of the campaign, most notably the personal experiences of the common soldier, but it has not included any comprehensive strategic and tactical analysis to compare with our book. And to the extent that the books surveyed have dealt with these subjects, they have tended to reinforce our findings.

There is one further issue we wish to address in this new Introduction. It should be clear from the summary above, and will be made even clearer in the course of the book, that we maintain that Passchendaele was one of the most futile campaigns waged by Britain in the Great War. But what we are not saying is that futile episodes such as this

${ }^{5}$ Jack Sheldon, The German Army at Passchendaele (Barnsley: Pen \& Sword, 2007).

${ }^{6}$ Michael LoCicero, A Moonlight Massacre: the Night Operation on the Passchendaele Ridge, 2 December 1917 (Birmingham: Helion, 2014).

${ }^{7}$ Jim Beach, Haig's Intelligence: GHQ and the German Army, 1916-1918 (Cambridge: Cambridge University Press, 2013).

${ }^{8}$ Sanders Marble, British Artillery on the Western Front in the First World War (Farnham: Ashgate, 2013). 
rendered Britain's entry into the war futile as a whole. The great engine of this war was Imperial Germany. Its expansionist plans which, despite the fact that the 1914 crisis had its origins in Eastern Europe, involved the invasion and eventual incorporation into the Reich of significant sections of Belgium and eastern France, threatened to create an industrial super-state that would dominate Europe and eventually Britain. This was to be no benevolent economic union under German leadership as fatuously suggested by Niall Ferguson. ${ }^{9}$ The Kaiser and his gang, it is necessary to point out, were not the equivalent of the governments of Willy Brandt, Gerhard Schroeder or Angela Merkel. Domination, not benevolence, was their aim, and military aggression their means. In short, the stakes in this war were no less than the survival of the liberal democracies of Western Europe.

Nor can we see any equivalence in the actions of other states and those of Germany. In the first place, without German backing Austria would not have sought war with Serbia. And what aggressive intentions did such countries as Belgium, France and Britain harbour against European states? In The Sleepwalkers, Christopher Clark argues that it is futile to point the finger at a guilty state in 1914, as it would assume, in his opinion, that in 'conflictual interactions' (by which we take him to mean 'war') 'one protagonist ultimately must be right and the other wrong. ${ }^{10}$ We would draw his attention to two states in 1914: Germany and Belgium. Belgium had played no role in the general crisis that engulfed Europe, had no interests to defend in Eastern Europe and was neutral. It nevertheless suffered wholesale invasion by Germany, followed in short order - as John Horne has reminded us by the massacre of more than 8,000 of its civilians and large-scale deportations of its male population to forced labour in the Reich. ${ }^{11}$ One of the reasons the war was still being prosecuted in 1917 was that Germany refused any peace deal that would have seen it withdraw from Belgium. As far as Germany was concerned, Belgium was its to keep and exploit. (This must go at least some way to answering the eminent military historian John Keegan's puzzlement about why, after such blood-letting, the war continued. $)^{12}$ We also wish to draw Clark's

\footnotetext{
9 Niall Ferguson, The Pity of War (London: Allen Lane, 1998).

${ }^{10}$ Christopher Clark, The Sleepwalkers: How Europe Went to War in 1914 (London: Allen Lane, 2012).

${ }^{11}$ John Horne and Alan Kramer, German Atrocities, 1914: A History of Denial (New Haven/London: Yale University Press, 2001).

${ }_{12}$ For Keegan's views see his The First World War (London: Hutchinson, 1998) and also his letter to the Times Literary Supplement, 'The Enigma of the Great War', 27 July 2001.
} 
attention to Britain, whose decision to enter the war was sparked by the German attack on Belgium and France. This was no whimsical act: Britain had no choice if it wished to maintain its independence. The accretion of industrial strength that Germany would have garnered by its conquests would have allowed it to become the largest naval power in the world. Once Germany had achieved dominance at sea equal to its dominance on land, Britain's day as an independent, self-sustaining power would have been done. During the crisis, therefore, Britain was reacting to events which threatened. Some finger-pointing in the German elites' direction is surely in order.

Nor can the Tsar's regime be substituted for that of the Kaiser as the main villain in 1914, as Sean McMeekin seeks to do. ${ }^{13}$ For McMeekin, it was the Russian decision to mobilize its forces in pursuance of its aim to incorporate Constantinople within its empire that led to war. But this completely misreads what was involved in Russian mobilization. It did not mean war and, as Dominic Lieven has pointed out, was not meant to; it was a slow and cumbersome process that, anyway, was aimed in the first instance not at Germany but at Austria. ${ }^{14}$ It did, however, gift the German leadership a propaganda weapon which they could wield against the Tsar, blaming him for the war. While many at the time fell for this ploy, there is no reason we should continue to a century on.

To sum up, we do not consider recent scholarship to have made any serious dents in what is called the Fischer Thesis on the origins of the First World War. In particular, Germany's naked aggression in Western Europe will always count heavily against it, and talk of 'sleepwalking' - were the German armies that invaded France and Belgium propelled by people who were asleep? - will not alter that stark fact. In 1917 the British, with much ineptitude, and little sense of what was possible, were still trying to remove the invaders from Belgium. But we must not allow this episode of futility to be equated with the view that the men who fought in this battle fought for nothing. Fighting to free Western Europe from the invader was definitely not futile. It is just that the cause deserved better leadership on the British political and military fronts than was on offer in the Passchendaele campaign of 1917.

Robin Prior Trevor Wilson January 2016

${ }^{13}$ Sean McMeekin, The Russian Origins of the First World War (Cambridge, MA: Harvard University Press, 2013).

${ }^{14}$ Dominic Lieven, Towards the Flame: Empire, War and the End of Tsarist Russia (London: Allen Lane, 2015). 